\title{
A concise and straightforward approach to total synthesis of (+)- Strictifolione and formal synthesis of Cryptofolione via a unified strategy
}

Left Running Head: X. LI ET AL.

Right Running Head: SYNTHETIC COMMUNICATIONS ${ }^{\circledast}$

\author{
Xiaotong Li ${ }^{1 *}$ Gaopeng Wang ${ }^{1 *}$ Zhibin Zhang $^{1 *} \mathrm{Na} \mathrm{Wu}{ }^{3}$ Qianqian Yang ${ }^{2}$ Shuangping Huang \\ $1{ }^{*}$ Xiaoji Wang ${ }^{2}$ * \\ ${ }^{1}$ School of Pharmacy, Jiangxi Science and Technology Normal University, Nanchang, China; \\ ${ }^{2}$ School of Life Science, Jiangxi Science and Technology Normal University, Nanchang, China; \\ ${ }^{3}$ School of Chemistry and Pharmaceutical Sciences, Key Laboratory for the Chemistry and Molecular Engineering of Medicinal Re- \\ sources, Guangxi Normal University, Guilin, China \\ *These three authors contributed equally to this work.
}

Color versions of one or more of the figures in the article can be found online at www.tandfonline.com/lsyc.

Supplemental data for this article is available online at on the publisher's website

*CONTACT Shuangping Huang 185544590@qq.com School of Pharmacy, Jiangxi Science and Technology Normal University, Nanchang, China.[AQ2]

Received: 2018-12-10

Revised: 2019-02-02

Accepted: 2019-02-04

(C) 2019 Taylor \& Francis Group, LLC

Taylor \& Francis

\section{ABSTRACT}

We describe a concise and straightforward approach to the total syntheses of (+)-Strictifolione and Cryptofolione in the longest linear sequences of four steps and six steps from 3-phenyl propanal and trans-cinnamaldehyde, respectively. The route utilized a titanium tetraisopropoxide/(R)-[1,1'-binaphthalene]-2,2'-diol catalyzed Mukaiyama aldol reaction, indium(0)-promoted Barbier reaction, and olefin cross-metathesis as the key reactions.

\section{GRAPHICAL ABSTRACT}
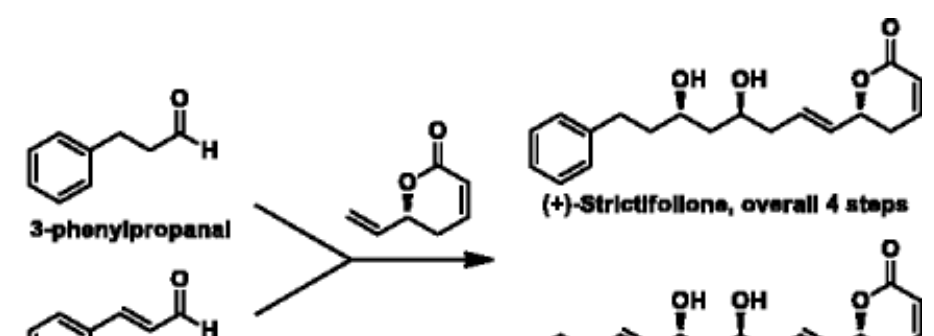

3-phenylpropanal
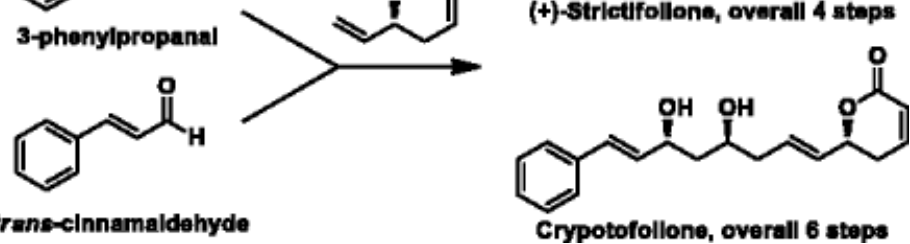

trane-cinnamaldehyde

Crypotofollone, overall 6 steps

KEYWORDS Strictifolione; Cryptofolione; total synthesis; Barbier reaction; olefin cross-metathesis

\section{FUNDING}


National Science Foundation of China, 21062088, 21562020, 21462004

Science and Technology Plan Project of Jiangxi Province, 20151BBG70028, 20142BBE50006

State Key Laboratory for the Chemistry and Molecular Engineering of Medicinal Resources, CMEMR2014-A04

We thank the National Science Foundation of China [21062088, 21562020, and 21462004], the Science and Technology Plan

Project of Jiangxi Province [No. 20151BBG70028, 20142BBE50006] and State Key Laboratory for the Chemistry and Molecular

Engineering of Medicinal Resources [CMEMR2014-A04] for the funding support.

\section{Introduction}

The potential Michael acceptor, $\alpha, \beta$-unsaturated $\delta$-lactone (also named 5,6-dihydro- $\alpha$-pyrone) is found in many natural products possessing useful pharmacological properties, such as anti-inflammatory, antiproliferative and anticancer activity. ${ }^{[1]}$ The related natural products include Strictifolione, Cryptofolione, Lactone monoalcohol, [2] Kurzilactone, [3] Passifloricin A, ${ }^{[4]}$ Tarchonanthuslactone ${ }^{[5]}$ (Figure 1). (+)-Strictifolione was isolated by Aimi et al. from the stem bark of Cryptocaria strictifolia which is indigenous to the Indonesian tropical rainforest. ${ }^{[6]}$ The relative stereochemistry of Strictifolione's structure was elucidated based on the spectroscopic method and the absolute configuration of the three chiral centers was established by Aimi's group in 2002 through its first total synthesis. ${ }^{\text {[7a] Cryptofolione }}$ was isolated from Cryptocarya latifolia, C. myrtifolia and C. alba ${ }^{[8]}$ and its structure was determined through an asymmetric total synthesis in 2005. [9a] Cryptofolione showed interesting bioactivity, such as reducing the number of Trypanosoma cruzi trypanosomastigotes by $77 \%$ at $250 \mu \mathrm{g} / \mathrm{mL}$, demonstrating cytotoxicity in both macrophages and T. cruzi amastigotes, and displaying inhibitory effects on the promastigote form of Leishmania species amongst others. ${ }^{[10]}$

Figure 1. Example of natural products possessing $\alpha, \beta$-unsaturated $\delta$-lactone.<smiles>O=C1C=CC[C@H](/C=C/C[C@H](O)C[C@H](O)CCc2ccccc2)O1</smiles>

(+)-strictfollone<smiles>O=C(/C=C/c1ccccc1)C[C@H](O)C[C@@H]1CC=CC(=O)O1</smiles>

Kurzllactone<smiles>O=C1C=CC[C@@H](C[C@@H](O)CCCCc2ccccc2)O1</smiles>

Lactone monoalcohol

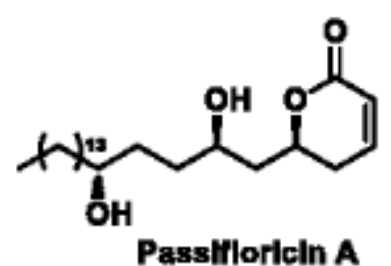<smiles>O=C1C=CC[C@H](/C=C/C[C@H](O)C[C@H](O)/C=C/c2ccccc2)O1</smiles>

(+)-Cryptofolione

As two typical members of this class of natural products containing an $\alpha, \beta$-unsaturated $\delta$-lactone moiety, syn- or anti-1,3-diol or 1,3,5-triol and a lipophilic subunit, (+)-Strictifolione and Cryptofolione attracted considerable interests in their total syntheses. Over the past decade, many efforts have been made towards the total syntheses of Stricti- 
folione ${ }^{[7]}$ and Cryptofolione ${ }^{[9]}$. Strictifolione has almost the same structure as Cryptofolione except for the saturated bond at $\mathrm{C}^{\prime}$-C 8 '; both have a 1,3-anti diol unit connecting the C-6 substituent of the $\alpha, \beta$-unsaturated $\delta$-lactone moiety with a double bond. Most of the published synthetic routes for Strictifolione and Cryptofolione involved scission of the unsaturated bond at $\mathrm{C1}^{\prime}-\mathrm{C} 2^{\prime}$ utilizing a convergent strategy. For the construction of stereogenic centers, many and varied protocols were employed, such as chiral pool syntheses, ${ }^{[7 \mathrm{e}]}$ enantioselective allyltitanation, ${ }^{[7 \mathrm{~b}]}$ enzymatic reduction, ${ }^{[7 \mathrm{j}]}$ asymmetric acetate aldol reaction ${ }^{[9 f]}$ and so on. Curiously, there is no synthetic report of these two molecules using a unified synthetic strategy. The shortest approach was explored by Hanson, who recently applied a threepot process to accomplish a modular approach toward $(+)$-Strictifolione and the related natural products. ${ }^{[7 \mathrm{k}]}$ As a part of our research aimed at developing a concise synthesis of natural products possessing an $\alpha, \beta$-unsaturated $\delta$-lactone, ${ }^{[11]}$ we decided to devise a unified, concise and efficient route to (+)-Strictifolione and Cryptofolione. It appears that the key to a shorter total synthesis is fewer synthetic steps towards the fragments. Therefore, here we describe a concise and practical total synthesis of (+)-Strictifolione and Cryptofolione through rapid preparation of two fragments.

\section{Results and discussion}

Our retrosynthetic analysis is shown in Scheme 1. (+)-Strictifolione and Cryptofolione were disconnected into two similar fragments, $\mathbf{1 - S} / \mathbf{1}-\mathbf{C}$ and $\mathbf{2}$, via a cross-metathesis reaction. For the fragment 1-S/1-C, the 1,3-anti-diol was assumed to be obtained via an In (0) promoted Barbier allylation from aldehyde 3-S/3-C, ${ }^{[12]}$ which would be readily prepared from aldehyde 5-S/5-C using a Crimmins modified Evans aldol reaction. ${ }^{[13]}$ Another known building block $2^{[7 f, h, j]}$, was devised to be readily prepared from $\delta$-hydroxyl $\beta$-keto ester $\mathbf{4}$, in which the chiral hydroxyl might be achieved employing an asymmetric Muakiyama aldol reaction. ${ }^{[9 e, 14]}$

Scheme 1. Retrosynthetic analysis of Strictifolione and Cryptofolione.

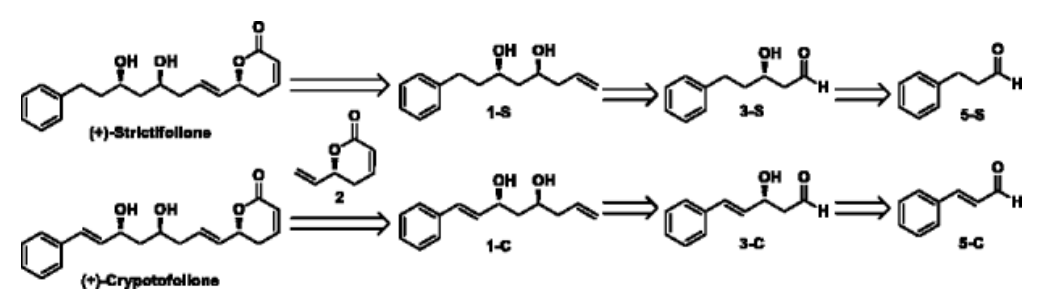

As shown in Scheme 2, we began our synthesis of (+)-Strictifolione with the preparation of fragment 1-S, using commercially available 3-phenyl propanol 5-S. 3-phenyl propanol was subjected to a Crimmins modified Evans aldol reaction when treated with compound 7 in the presence of $\mathrm{TiCl}_{4}$ and DIPEA to give 8 in a yield of $84 \%(\mathrm{dr}=2.5: 1)$. Alcohol $\mathbf{8}$ then needed to be reduced to $\beta$-hydroxyl aldehyde 3-S. The presumed instability of 3-S was evident, so the crude 3-S was immediately subjected to the subsequent Barbier reaction.

Scheme 2. Synthetic route of intermediate 1-S. Reagents and conditions: (a) $\mathrm{TiCl}_{4}$, DIPEA, $\mathrm{CH}_{2} \mathrm{Cl}_{2},-78{ }^{\circ} \mathrm{C}, 84 \%$ (d.r. $=2.5: 1$ ); (b) DIBAL-H, $\mathrm{CH}_{2} \mathrm{Cl}_{2},-78^{\circ} \mathrm{C}$.

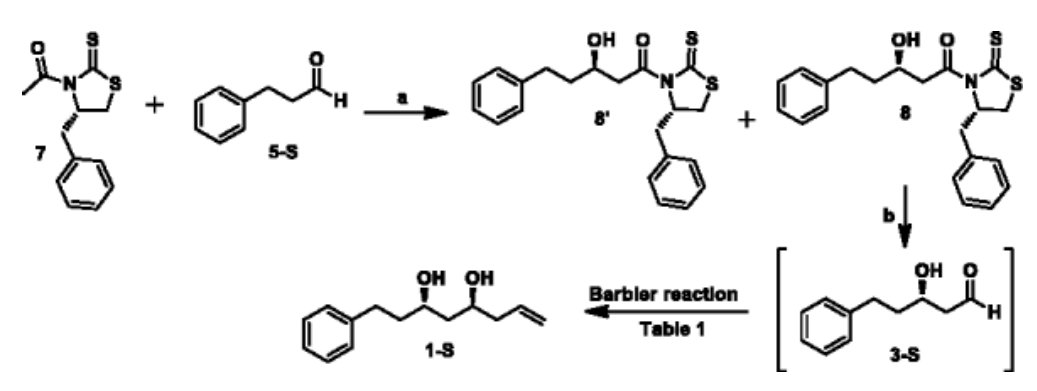

Following Li's protocol, ${ }^{[12 \mathrm{a}]}$ we first attempted the allylation in water, however, we only obtained the 1,3-diol 1-S in $60 \%$ after $72 \mathrm{~h}$ with no diastereoselectivity (entry 1 in Table 1). This disappointing ratio impelled us to optimize 
this transformation. As shown in Table 1, by simply adjusting the ratio of solvent (water to THF), we found the desired 1-S was obtained in 55\% over two steps with the dr ratio of $6: 1$ (anti: syn) when using $\mathrm{THF} / \mathrm{H}_{2} \mathrm{O}(1: 1)$ as the solvent mixture (entry 2). However, increasing the ratio of THF only resulted in poor diastereoselectivity (entry 3 ) and yield (entry 4).

Table 1. Optimization of Barbier reaction. Table Layout

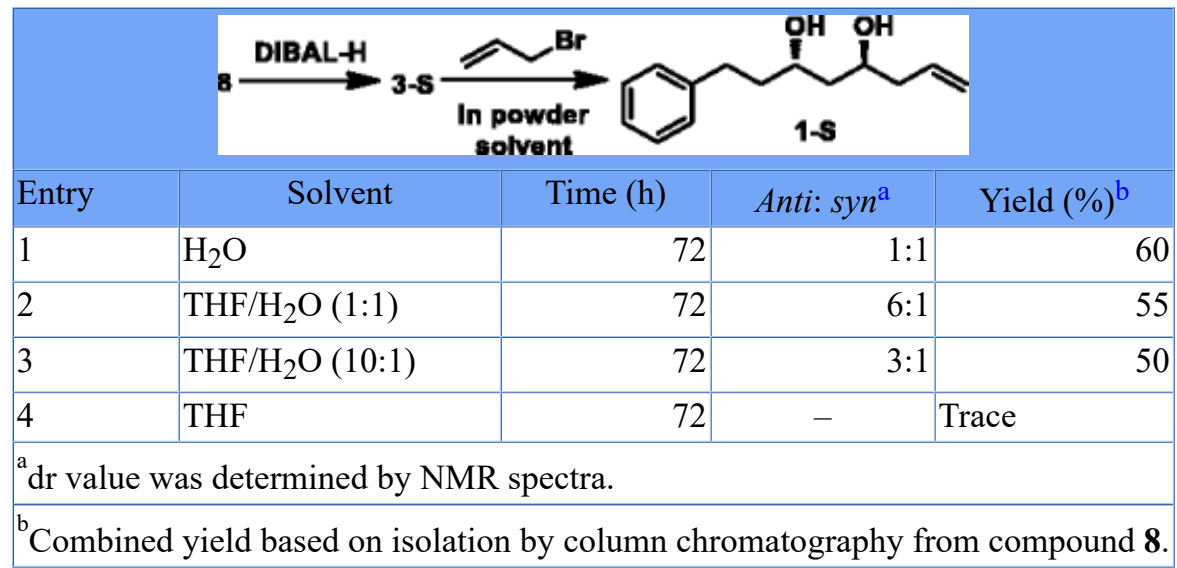

Synthesis of fragment 2 started from acrylaldehyde 6. Retrosynthetically, the chiral hydroxyl was installed through Mukaiyama aldol reaction. Thus, the addition of acrylaldehyde 6 to Chan's diene in the presence of $\operatorname{Ti}\left(\mathrm{O}^{\mathrm{i}} \mathrm{Pr}\right)_{4} /(R)$ BINOL and molecular sieves in THF at $-78{ }^{\circ} \mathrm{C}$ afforded $\delta$-hydroxyl $\beta$-keto ester 4 smoothly in $83 \%$ yield with $96 \%$ ee value (Scheme 3). Considering the requirement for a $\beta$-hydroxyl, the intermediate 4 was then subjected to reduction with $\mathrm{NaBH}_{4}$ to furnish diol 10 in $85 \%$ without determination of dr value. Cyclization of $\mathbf{1 0}$ with PPTS in refluxing benzene smoothly afforded lactone $\mathbf{1 1}$ in a yield of $95 \%$. The compound $\mathbf{1 1}$ was subsequently treated with $\mathrm{MsCl}$ and triethylamine in DCM at $0{ }^{\circ} \mathrm{C}$ to give fragment 2 via a one-pot process in $80 \%$ yield. At higher temperature, the desired fragment 2 was able to be prepared from $\mathbf{1 0}$ directly. ${ }^{[15]}$ Thus, lactone $\mathbf{2}$ was obtained from diol $\mathbf{1 0}$ in $90 \%$ by refluxing in toluene (Scheme 3)[AQ3].

Scheme 3. Synthesis of intermediate 2. Reagents and conditions: (a) $\mathrm{Ti}\left(\mathrm{O}^{\mathrm{i}} \mathrm{Pr}\right)_{4},(R)$-BINOL, THF, $-78{ }^{\circ} \mathrm{C}, 83 \%, 96 \%$ ee; (b) $\mathrm{NaBH}_{4}, \mathrm{MeOH}, 0{ }^{\circ} \mathrm{C}, 85 \%$; (c) PPTS, benzene, reflux, $95 \%$; (d) $\mathrm{MsCl}, \mathrm{Et}_{3} \mathrm{~N}, \mathrm{CH}_{2} \mathrm{Cl}_{2}, 0{ }^{\circ} \mathrm{C}, 80 \%$; (e) PPTS, toluene, reflux, $90 \%$.

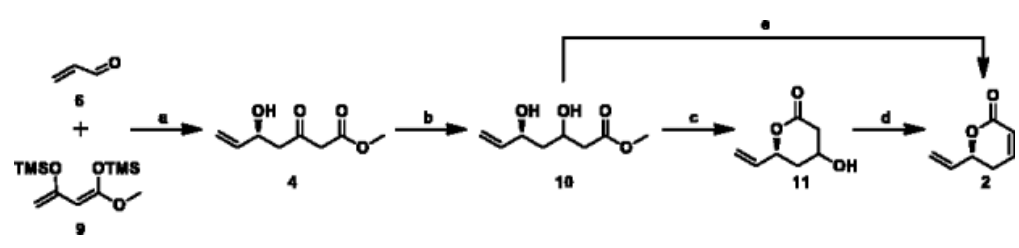

With fragment 1-S and $\mathbf{2}$ in hand, we conducted the cross-metathesis coupling of two fragments. Following the known procedure, $\left.{ }^{[7} \mathrm{j}\right]$ the olefin cross-metathesis reaction of $\mathbf{1 - S}$ and $\mathbf{2}$ in the presence of Grubbs' second generation catalyst furnished (+)-Strictifolione (Scheme 4).

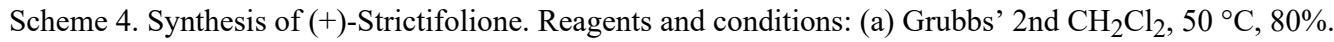

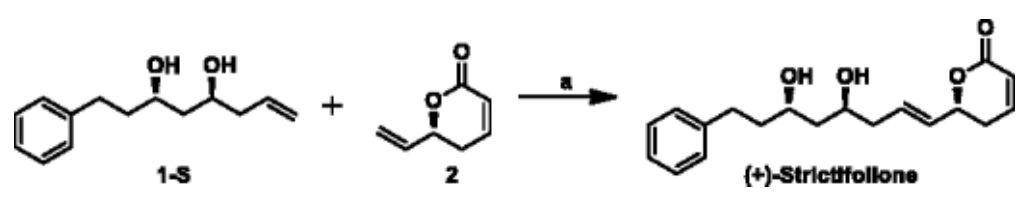


The same synthetic sequence described above was applied to Cryptofolione by replacing 3-phenyl propanol with trans-cinnamaldehyde. As depicted in Scheme 5, Crimmins modified Evans aldol reaction of cinnamaldehyde and compound 7 easily gave alcohol $\mathbf{1 2}$ following Yadav's procedure. ${ }^{[9 f]}$ The prepared $\mathbf{1 2}$ was subjected to a DIBAL-H reduction to prepare aldehyde 3-C, and then, without purification, the crude of aldehyde 3-C was subjected to the In (0)-promoted Barbier reaction in THF/ $\mathrm{H}_{2} \mathrm{O}(10: 1)$ to afford anti-diol 1-C in $75 \%$ yield over two steps with moderate diastereoselectivity $(\mathrm{dr}=4: 1)$. 1-C was too difficult to be separated efficiently from its diastereoisomer. However, when they were subjected to protection with 2,2-dimethoxypropane, 1-C would be obtained in $20 \%$ accompanied by the protected diol mixtures $\mathbf{1 3}^{\prime} . \mathbf{1 3}^{\prime}$ were then treated with $4 \mathrm{~N} \mathrm{HCl}$ gave the free diols, which then performed the above kinetic resolution. After three kinetic resolutions, we could obtain about one half of 1-C (48\%) from the mixture of the diastereoisomers.

Scheme 5. Synthetic route of intermediate 1-C. Reagents and conditions: (a) see ref. [9f]]; (b) DIBAL-H, $\mathrm{CH}_{2} \mathrm{Cl}_{2}$; (c) In powder, 3bromoprop-1-ene, THF: $\mathrm{H}_{2} \mathrm{O}=1: 1,75 \%$ (d.r. = 4:1) over two steps; (d) p-TsOH, $\mathrm{CH}_{2} \mathrm{Cl}_{2}$, 2,2- dimethoxypropane, $0{ }^{\circ} \mathrm{C}, 5.5 \mathrm{~h}$; (e) $4 \mathrm{~N} \mathrm{HCl}, \mathrm{MeCN}, 0{ }^{\circ} \mathrm{C}, 93 \%$.

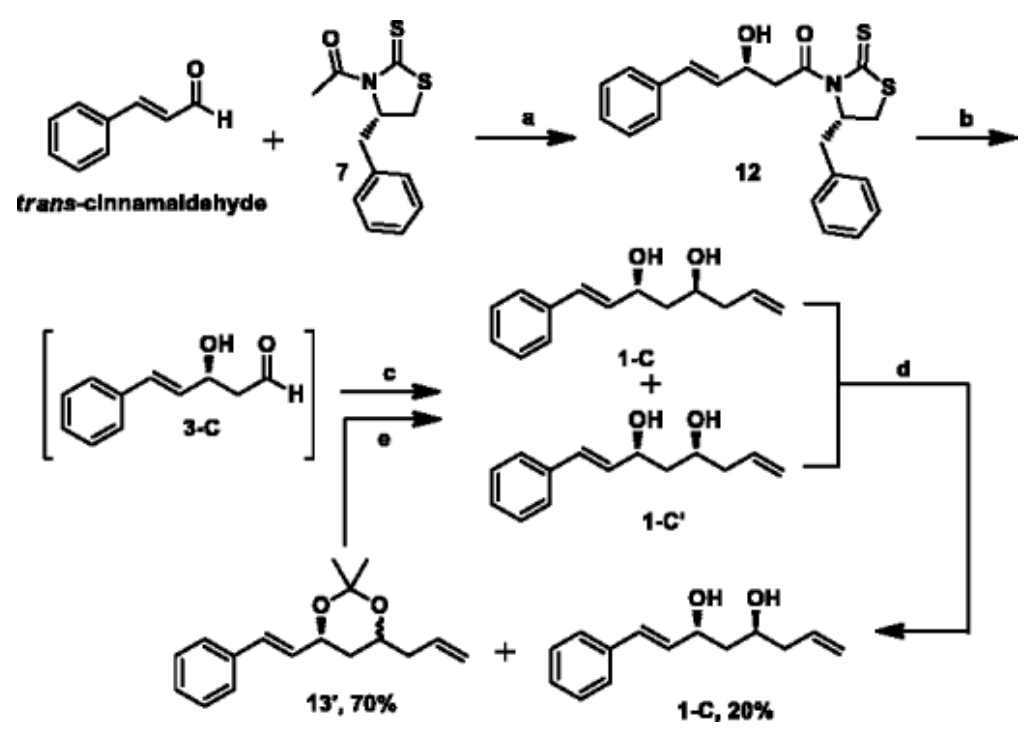

An attempt to conduct the cross-metathesis reaction of compound 1-C with fragment $\mathbf{2}$ failed, therefore, the hydroxyls of 1-C were subsequently protected with 2,2-dimethoxypropane to give the intermediate 13, previously reported as a fragment, which was coupled with lactone $\mathbf{2}$ to easily furnish Cryptofolione via a CM reaction (Scheme 6). ${ }^{9 \mathrm{c}]}$ The physical and spectral data $\left({ }^{1} \mathrm{H},{ }^{13} \mathrm{C}\right)$ of compound $\mathbf{1 3}$ from our lab were in agreement with those reported in the literature (Scheme 6).

Scheme 6. Formal synthesis of Cryptofolione. Reagents and conditions: (a) p- $\mathrm{TsOH}, \mathrm{CH}_{2} \mathrm{Cl}_{2}, 2$,2-dimethoxy-propane, $0{ }^{\circ} \mathrm{C}$, overnight, $83 \%$.

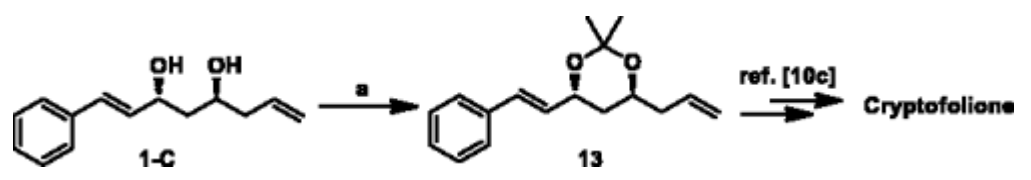

\section{Conclusion}

Thus, we have successfully achieved the total synthesis of (+)-Strictifolione and formal synthesis of Cryptofolione via a unified strategy. To the best of our knowledge, the present synthetic route represents the shortest route to these two molecules. We separated the target into two fragments, and the linear route was only 4 steps and 6 steps for (+)- 
Strictifolione and Cryptofolione respectively. This synthetic approach provides an alternative route to these natural products of similar structure.

\section{Experimental}

All air and water sensitive reactions were carried out under a nitrogen atmosphere with dry solvents under anhydrous conditions unless otherwise noted. All the chemicals were purchased commercially and used without further purification. Anhydrous THF and was distilled from sodium-benzophenone, toluene was distilled from sodium, and dichloromethane was distilled from calcium hydride. Reactions were monitored by thin-layer chromatography (TLC) carried out on $0.25 \mathrm{~mm}$ silica gel plates (60F-254) that were analyzed by staining with $\mathrm{KMnO}_{4}\left(200 \mathrm{~mL} \mathrm{H}_{2} \mathrm{O}\right.$ of $1.5 \mathrm{~g}$ $\mathrm{KMnO}_{4}, 10 \mathrm{~g} \mathrm{~K}_{2} \mathrm{CO}_{3}$ and $1.25 \mathrm{~mL}$ of $10 \%$ aqueous $\mathrm{NaOH}$ ), fluorescence upon $254 \mathrm{~nm}$ irradiation or by staining with anisaldehyde (450 mL of 95\% EtOH, $25 \mathrm{~mL}$ of conc. $\mathrm{H}_{2} \mathrm{SO}_{4}, 15 \mathrm{~mL}$ of acetic acid, and $25 \mathrm{~mL}$ of anisaldehyde). Silica gel (60, particle size $0.040-0.063 \mathrm{~mm}$ ) was used for flash chromatography. IR spectra were obtained using FT-IR Spectrometer. NMR spectra were recorded on either a $300\left({ }^{1} \mathrm{H}: 300 \mathrm{MHz},{ }^{13} \mathrm{C}: 75 \mathrm{MHz}\right), 400\left({ }^{1} \mathrm{H}: 400 \mathrm{MHz},{ }^{13} \mathrm{C}\right.$ : $100 \mathrm{MHz})$, or $500\left({ }^{1} \mathrm{H}: 500 \mathrm{MHz},{ }^{13} \mathrm{C}: 125 \mathrm{MHz}\right)$. The following abbreviations were used to explain the multiplicities: s: singlet; d: doublet; t: triplet; q: quartet; m: multiplet; b: broad. High-resolution mass spectra were obtained from a MALDI-TOF mass spectrometer.

\section{(3S,5S)-1-phenyloct-7-ene-3,5-diol (1-S)}

To a stirred mixture of $8(0.2 \mathrm{~g}, 0.52 \mathrm{mmol})$ in THF $(5 \mathrm{~mL})$ was added DIBAL-H $(1.5 \mathrm{mmol}, 1.5 \mathrm{~mL}, 1 \mathrm{M}$ in toluene) dropwise at $-78{ }^{\circ} \mathrm{C}$. After stirring at $-78{ }^{\circ} \mathrm{C}$ for 0.5 hour, the reaction was quenched by addition of a saturated potassium sodium tartrate aqueous solution $(20 \mathrm{~mL})$, and the aqueous phase was extracted with ethyl acetate $(50 \mathrm{~mL} \times 3)$. The combined organic extracts were washed with brine, dried over $\mathrm{Na}_{2} \mathrm{SO}_{4}$, filtered and concentrated and gave a yellow oil as the crude product 3-S. Without further purification, the crude 3-S was used in the next reaction.

To a stirred solution of crude $3-\mathrm{S}$ in $\mathrm{THF} / \mathrm{H}_{2} \mathrm{O}$ ( $\mathrm{vol} / \mathrm{vol}=1: 1,5 \mathrm{~mL}$ ) was added Indium powder (72 $\mathrm{mg}$, $0.62 \mathrm{mmol})$ and allyl bromide $(70 \mu \mathrm{L}, 0.75 \mathrm{mmol})$. The resulting mixture was stirred at room temperature till the aldehyde 3-S was consumed. Then the reaction was diluted by addition of ethyl acetate $(5 \mathrm{~mL})$, and the aqueous phase was extracted with ethyl acetate $(5 \mathrm{~mL} \times 2)$. The combined organic extracts were washed with brine, dried over $\mathrm{Na}_{2} \mathrm{SO}_{4}$, filtered and concentrated. Silica gel flash column chromatography (hexanes/ethyl acetate $=5: 1$ ) of the residue gave a yellow oil $(0.063 \mathrm{~g}, 0.29 \mathrm{mmol}, 55 \%($ d.r. $=6: 1))$ as the product $\mathbf{1 - S}$.

$[\alpha]_{\mathrm{D}}{ }^{25}=+4.23\left(\mathrm{c}=1.0, \mathrm{CHCl}_{3}\right) ;{ }^{1} \mathrm{H}$ NMR $\left(300 \mathrm{MHz}, \mathrm{CDCl}_{3}\right) \delta 7.34-7.14(\mathrm{~m}, 5 \mathrm{H}), 5.88-5.72(\mathrm{~m}, 1 \mathrm{H}), 5.16(\mathrm{~d}$, $J=1.0 \mathrm{~Hz}, 1 \mathrm{H}), 5.14-5.09(\mathrm{~m}, 1 \mathrm{H}), 4.06-3.92(\mathrm{~m}, 2 \mathrm{H}), 2.73(\mathrm{dddd}, J=34.3,13.7,9.6,6.3 \mathrm{~Hz}, 2 \mathrm{H}), 2.31-2.22$ $(\mathrm{m}, 2 \mathrm{H}), 1.92-1.72(\mathrm{~m}, 2 \mathrm{H}), 1.69-1.63(\mathrm{~m}, 2 \mathrm{H}) ;{ }^{13} \mathrm{C} \mathrm{NMR}\left(75 \mathrm{MHz}, \mathrm{CDCl}_{3}\right) \delta 142.09,134.61,128.55,128.52$, 125.99, 118.54, 68.93, 68.37, 42.12, 41.99, 39.15, 32.32; IR: 3347, 1641, 1496, 1454; HRMS: $\mathrm{m} / z$ calcd. for $\mathrm{C}_{14} \mathrm{H}_{20} \mathrm{NaO}_{2}[\mathrm{M}+\mathrm{Na}]^{+}$243.1356, found 243.1356.

Full experimental detail and ${ }^{1} \mathrm{H}$ and ${ }^{13} \mathrm{C}$ NMR spectra, HPLC traces can be found via the Supplementary Content section of this article's Web page.

\section{References}

1. (a) Jodynis-Liebert, J.; Murias, M.; Błoszyk, E. Effect of Sesquiterpene Lactones on Antioxidant Enzymes and Some Drug-metabolizing Enzymes in Rat Liver and Kidney. Planta Med. 2000, 66, 199-205. DOI: 10.1055/ s-2000-8566. (b) Drewes, S. E.; Horn, M. H.; Mavi, S. Cryptocarya Liebertiana and Ocotea Bullata-Their Phytochemical Relationship. S. Phytochemistry. 1997, 44, 437. DOI: 10.1016/S0031-9422(96)00464-5 . (c) Zschocke, S.; van Staden, J. J. Cryptocarya Species-Substitute[AQ10] Plants for Ocotea Bullata? A Pharmacological Investigation in Terms of Cyclooxygenase-1 and -2 Inhibition. J. Ethnopharmacol. 2000, 71, 473. - awariah, A.; Stanslas, J. In Vitro Response of Human Breast Cancer Cell Lines to the Growth-inhibitory Effects (SPD) and Assessment of its Antiestrogenicity. Anticancer Res. 1998, 18, 4383. (e) Pihie, A. H. L.; Stanslas, J.; Din, L. B. Non-Steroid Receptor-mediated Antiproliferative Activity of Styrylpyrone Derivative in Human Breast Cancer 
Cell lines. Anticancer Res. 1998, 18, 1739. (f) Ee, Y. S.; Lai, L. C.; Reimann, K.; Lim, P. K. Effect of Transforming Growth Factor-betal on Oestrogen Metabolism in MCF-7 and MDA-MB-231 Breast Cancer Cell lines. Oncol. Rep. 1999, 6, 843.

2. Raoelison, E. ;erreaux, C.; Queiroz, E. F.; Zsila, F.; Simonyi, M.; Antus, S.; Randriantsoa, A.; Hostettmann, K. Absolute Configuration of Two New 6-Alkylateda-Pyrones (=2H-Pyran-2-ones) fromRavensara Crassifolia. HCA. 2001, 84, 3470-3476. DOI: 10.1002/1522-2675(20011114)84:11<3470::AID-HLCA3470>3.0.CO;2-K.

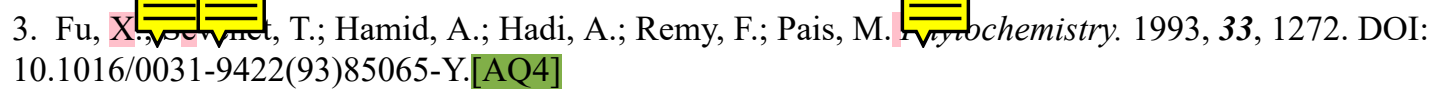

4. Echeverri, F.; Arango, V.; Quiñones, W.; Torres, F.; Escobar, G.; Rosero, Y.; Archbold, R. Passifloricins, polyketides alpha-pyrones from Passiflora Foetida resin. Phytochemistry. 2001, 56, 881-885. DOI: 10.1016/ S0031-9422(00)00478-7.

5. Bohlmann, F.; Suwita, A. Ein Neues Bisabolen-Derivat Und Ein Neues Dihydro Kaffeesäure-Derivat Aus Tarchonanthus Trilobus. Phytochemistry. 1979, 18, 677-679. DOI: 10.1016/S0031-9422(00)84293-4.

6. Juliawaty, L. D.; Kitajima, M.; Takayama, H.; Achmad, S. A.; Aimi, N. A 6-substituted-5,6-dihydro-2-pyrone from Cryptocarya Strictifolia. Phytochemistry. 2000, 54, 989-993. DOI: 10.1016/S0031-9422(00)00077-7.

7. (a) Juliawaty, L. D.; Watanabe, Y.; Kitajima, M.; Achmad, S. A.; Takayama, H.; Aimi, N. First Total Synthesis and Determination of the Absolute Configuration of Strictifolione, a New 6-( $\omega$-Phenylalkenyl)-5,6-dihydro- $\alpha$-pyrone, isolated from Cryptocarya Strictifolia. Tetrahedron Lett. 2002, 43, 8657-8660. DOI: 10.1016/S0040-4039(02)02181-0. (b) Bouz, B. S.; Cossy, J. Jett. 2003, 5, 1995-1997. DOI: 10.1021/o1034619s[AQ5]. (c) Tosaki, S.-Y.; Nemoto, T.; Ohshima, T.; Shibasak E Catalytic[AQ10] Asymmetric Synthesis of Both Syn- and Anti-3,5-Dihydroxy Esters: Application to 1,3-Polyol/Alpha-Pyrone Natural Product Synthesis. Org. Lett. 2003, 5, 495-498. DOI: 10.1021/ ol0273708. (d) Enders, D.; Lenzen, A.; Muller, M. Efficient Asymmetric Syntheses of (+)-Strictifolione. Synthesis. 2004, 2004, 1486-1496. DOI: 10.1055/s-2004-822387. (e) Ramana, C. V.; Raghupathi, N.; Gurjar, M. K.; Chorghade, M. S. A Carbohydrate-based Approach for the Total Synthesis of Strictifolione. Tetrahedron Lett. 2005, 46, 4073-4075. DOI: 10.1016/j.tetlet.2005.04.031. (f) Sabitha, G.; Fatima, N.; Gopal, P.; Reddy, C. N.; Yadav, J. S. Stereoselective Total Synthesis of (+)-Strictifolione and (6R)-6-[(4R,6R)-4,6-dihydroxy-10-phenyldec-1-enyl]-5,6-dihydro-2H-pyran-2-one by Prins Reaction and Olefin Cross-Metathesis. Tetrahedron Asymmetry. 2009, $20,184-191$. DOI: 10.1016/j.tetasy.2008.12.004. (g) Kumar, P.; Pandey, M.; Gupta, P.; Naidu, S. V.; Dhavale, D. D. Enantio- and Diastereocontrolled Total Synthesis of (+)-Strictifolione. Eur. J. Org. Chem. 2010, 2010, 6993-7004. DOI: 10.1002/ ejoc.201001221. (h) Das, B.; Veeranjaneyulu, B.; Balasubramanyam, P.; Srilatha, M. Stereoselective Total Synthesis of (+)-Strictifolione and (6R)-6[(E,4R,6R)-4,6-dihydro-10-phenyl-1-decenyl)-5,6-dihydro-2H-2-Pyrone. Tetrahedron: Asymmetry 2010, 21, 2762-2767. (i) Tang, S.; Xie, X.; Wang, X.; He, L.; Xu, K.; She, X. Concise Total Syntheses of (+)-Strictifolione and (6R)-6-[(4R,6R)-4,6-Dihydroxy-10-phenyldec-1-enyl]-5,6-dihydro-2 H -pyran-2-One. J. Org. Chem. 2010, 75, 8234-8240. hyay, S.; Sharma, A. A Chemoenzyr $\equiv$ Asymmetric Synthesis of (+)-Strictifolione. Tetrahedron Asymmetry. 2012, 23, 1093-1099. DOI: 10.1016/j.tetasy.2012.06.015. (k) Jayasinghe, S.; Venukadasula, P. K. M.; Hanson, P. R. An Efficient, Modular Approach for the Synthesis of (+)-Strictifolione and a Related Natural Product. Org. Lett. 2014, 16, 122-125. DOI: 10.1021/o1403110p. (l) Wang, X. J.; Wang, G. P.; Huang, S. P.; Zhang, Z. M.; Liu, S.; Chen, S. P. $C n-4604$ A 2016,[AQ6]

8. E (w) hlapelo, B. M.; Drewes, S. E.; Scott-Shaw, R. A 6-substituted 5,6-dihydro- $\alpha$-pyrone from Two Species of Cryptocarya. Phytochemistry. 1994, 37, 847. DOI: 10.1016/S0031-9422(00)90368-6. (b) Cavalheiro, A. J.; Yoshida, M. 6-[Omega-Arylalkenyl]-5,6-Dihydro-Alpha-Pyrones[AQ10] from Cryptocarya Moschata (Lauraceae). Phytochemistry. 2000, 53, 811. ehme, C. J.; Bastos, W. L.; De Arau J. Javalheiro, A. J. An HPLC-PAD Method to Analyse Flavonoid Gl: $\equiv$ es and Styrylpyrones from Cryptoc: $\equiv$ pecies (lauraceae). Phytochem. Anal. 2005, 16, 93.

9. (a) $1 . . . . . . .0 k a$, Y.; Aikawa, K.; Irie, R.; Katsuki, T. S(K)73[AQ7]. (b) Sabitha, G.; Reddy, S. S. S.; Reddy ; Bhaskar, V.; Yadav, J. S. Stereoselective Approaches to the Total Synthesis of (6R,4'S,6'R)-Cryptofolione.[AQ10] Synthesis. 2010, 2010, 3453-3460. DOI: 10.1055/ s-0030-1258215. (c) Balasubramanyam, P.; Reddy, G. C.; Salvanna, N.; Das, B. esis. 2011, 3706-3710. DOI: 10.1055/s-0030-1260246[AQ8]. (d) Das, B.; Nagendra, S.; Reddy, C. R. Stereos 
tofolione and (+)-Goniothalamin. Tetrahedron Asymmetry. 2011, 22, 1249-1254. DOI: 10.1016/j.tetasy.2011.06.029. (e) Kumar, R. N.; Meshram, H. M. Total Synthesis of (-)-Diospongin a and (+)-Cryptofolione via Asymmetric Aldol Reaction. Tetrahedron Lett. 2011, 52, 1003-1007. DOI: 10.1016/j.tetlet.2010.12.070. (f) Yadav, J. S.; Ganganna, B.; Bhunia, D. C. First Stereoselective Total Synthesis of Cryptomoscatone D2 and Syntheses of (5R,7S)-Kurzilactone and (+)-Cryptofolione by an Asymmetric Acetate Aldol Approach. Synthesis. 2012, 44, 1365-1372. DOI: 10.1055/ s-0031-1290771

10. Schmeda-Hirschmann, G.; Astudillo, L.; Bastida, J.; Codina, C.; Rojas de Arias, A.; Ferreira, M. E.; Inchaustti, A.; Yaluff, G. Cryptofolione Derivatives from Cryptocarya Alba fruits. J. Pharm. Pharmacol. 2001, 53, 563. DOI: $10.1211 / 0022357011775686$.

11. Huang, S. P.; Liu, D. W.; Tang, L. J.; Huang, F. F.; Yang, W.; Wang, X. J. t. 2015, 2023. DOI: 10.1055/s-0034-1378784.[AQ9]

12. (a) Li, C. J.; Chan, T. H. Organometallic Reactions in Aqueous Media with Indium. Tetrahedron Lett. 1991, 32, 7017-7020. DOI: 10.1016/0040-4039(91)85028-4. (b) Li, C. J. Aqueous Barbier-Grignard Type Reaction: Scope, Mechanism, and Synthetic Applications. Tetrahedron. 1996, 52, 5643-5668. DOI: 10.1016/0040-4020(95)01056-4.

13. (a) Lin, S. J.; Zhang, J. T.; Zhang, Z. B.; Xu, T. X.; Huang, S. P.; Wang, X. J. Asymmetric Total[AQ10] Synthesis of Ieodomycin B. Mar. Drugs. 2017, 15, 17. DOI: 10.3390/md15010017. (b) Hodge, M. B.; Olivo, H. F. Stereoselective Aldol Additions of Titanium Enolates of N-acetyl-4-isopropyl-Thiazolidinethione. Tetrahedron. 2004, 60, 93979403.

14. F. Imples: (a) Soriente, A.; De Rosa, M.; Villano, R.; Scettri, A. Enantioselective Aldol Condensation of 1,3bis-(Trimethylsilyloxy)-1-Methoxy-Buta-1,3-Diene Promoted by Chiral Ti(IV)/BINOL Complex. Tetrahedron Asymmetry. 2000, 11, 2255-2258. DOI: 10.1016/S0957-4166(00)00200-7. (b) Soriente, A.; De Rosa, M.; Stanzione, M.; Villano, R.; Scettri, A. An Efficient Asymmetric Aldol Reaction of Chan's Diene Promoted by Chiral Ti(IV)-BINOL Complex. Tetrahedron Asymmetry. 2001, 12, 959-963. DOI: 10.1016/S0957-4166(01)00150-1

15. Wolberg, M.; Dassen, B. H. N.; Schürmann, M.; Jennewein, S.; Wubbolts, M. G.; Schoemaker, H. E.; Mink, D. Large-Scale Synthesis of New Pyranoid Building Blocks Based on Aldolase-Catalysed Carbon-Carbon Bond Formation. Adv. Synth. Catal. 2008, 350, 1751-1759. DOI: 10.1002/adsc.200800224. 


\section{AUTHOR QUERIES}

Query: AQ1: Please review the table of contributors below and confirm that the first and last names are structured correctly and that the authors are listed in the correct order of contribution. This check is to ensure that your names will appear correctly online and when the article is indexed.

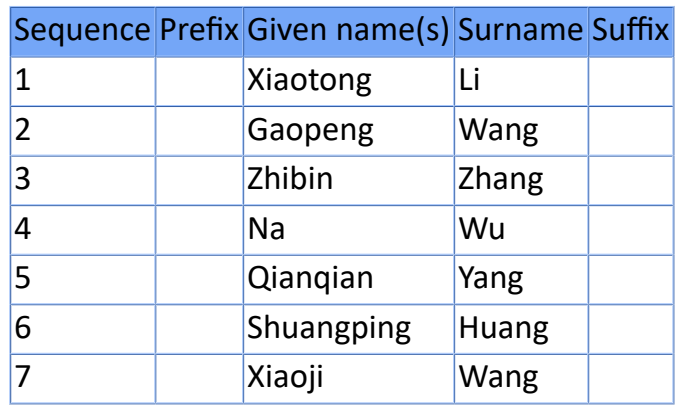

Response: Resolved

Query: AQ2: Please resupply the corresponding author details if it is inaccurate.

Response: Resolved

Query: AQ3: Schemes 3, 4, and 6 were not cited in the text, so a citation has been inserted. Please provide a correction if this is inaccurate.

Response: Resolved

Query: AQ4: Please provide the missing article title for the "[3]" references list entry.

Response: Resolved

Query: AQ5: Please provide the missing article title for the "7b" references list entry.

Response: Resolved

Query: AQ6: Please provide the missing article title and volume number and page range for the "[7I]" references list entry.

Response: Resolved

Query: AQ7: Please provide the missing article title for the "[9a]" references list entry.

Response: Resolved

Query: AQ8: Please provide the missing article title for the "[9c]" references list entry.

Response: Resolved

Query: AQ9: Please provide the missing article title and volume number for the "[11]" references list entry.

Response: Resolved

Query: AQ10: Please provide the missing DOI number for journal type references [1c,d,e,f]; [7i,l]; [8b,c]; [9c]; [13b]. Response: Resolved

\section{COMMENTS}

C1 Author: T.x; :

C2 Author: \&eacute;; :

C3 Author: Kurzilactone from Cryptocarya kurzii.; :

C4 Author: Total Synthesis of (+)-Strictifolione.; :

C5 Author: N; :

C6 Author: Natural product (+)-Strictifolione synthetic method.; :

C7 Author: Asymmetric Synthesis of Cryptofolione and Determination of Its Absolute Configuration.; :

C8 Author: Efficient Stereoselective Total Synthesis of (+)-Cryptofolione and the FirstSynthesis of (\&ndash;)-Cryptocaryalactone.; : 
C9 Author: 26, ; :

C10 Author: A Concise and Versatile Total Synthesis of All Stereoisomers ofTarchonanthuslactone.; :

C11 Author: . DOI: 10.1016/S0378-8741(00)00183-5.; :

C12 Author: DOI: 10.1021/jo101875w.; :

C13 Author: . DOI: 10.1016/S0031-9422(99)00532-4.; :

C14 Author: \&uacute;; :

C15 Author: . DOI: 10.1002/pca.818.; :

C16 Author: . DOI: 10.1016/j.tet.2004.08.008.; :

C17 Author: . DOI: 10.3892/or.6.4.843.; : 